\title{
Morphometric variation of the Herichthys bartoni (Bean, 1892) species group (Teleostei: Cichlidae): How many species comprise $\boldsymbol{H}$. labridens (Pellegrin, 1903)?
}

\author{
Omar Mejía ${ }^{1}$, Fabián Pérez-Miranda $^{1}$, Yatzil León-Romero ${ }^{1}$, Eduardo Soto-Galera $^{1}$ and \\ Efraín de Luna ${ }^{2}$
}

Cichlids of the tribe Heroini have long been a source of taxonomical conflict. In particular, the species included in the Herichthys bartoni group have failed to be recovered as monophyletic in different molecular studies. In this paper we use traditional and geometric morphometrics to evaluate morphological variation in the species included in the $H$. bartoni complex in order to evaluate the number of species it contains. An update of a previously published DNA barcoding study suggests the existence of three genetic clusters that included the six recognized species analyzed in this study, none of them recovered as monophyletic. On the other hand, geometric morphometrics arise as a useful tool to discriminate species due that traditional morphometrics showed a high overlap in the characters analyzed that prevents the proposal of diagnostic characters.

Los cíclidos de la tribu Heroini han experimentado un largo conflicto taxonómico. En particular, las especies incluidas en el grupo Herichthys bartoni no han sido recuperadas como monofiléticas en diversos estudios moleculares. En este artículo nosotros usamos morfometría tradicional y geométrica para evaluar la variación morfológica de las especies incluidas en el complejo H. bartoni para evaluar el numero de especies que contiene. Una actualización de un estudio previo de código de barras de ADN sugiere la existencia de tres grupos genéticos que incluyen las seis especies reconocidas analizadas en este estudio, ninguna de las cuales fue recuperada como monofilética. Por otro lado, la morfometría geométrica surge como una herramienta de utilidad para discriminar especies debido a que la variación en caracteres morfométricos tradicionales muestra altos niveles de solapamiento que previene la propuesta de caracteres diagnósticos.

Keywords: Cichlids, COI, DNA barcode, Geometric morphometrics, Mexico.

\section{Introduction}

Aquatic environments can show great spatial and temporal variations in both biotic and abiotic parameters. In these environments, many fish species show extreme morphological differences between highly contrasting habitats (Langerhans et al., 2003). Cichlids in particular are known for their spectacular adaptive radiation and high phenotypic plasticity, which makes this group an excellent model for ecological and evolutionary studies (Klingenberg et al., 2003). In the recent years, these high levels of variation have translated into a very unstable taxonomy, which has led to several nomenclatural changes and unclear boundaries among species. Originally, the genus Herichthys comprised four species that inhabit the coastal basins of the Gulf of Mexico from Texas to Veracruz (Miller, 1966). Later, Kullander (1996) included in Herichthys five species that had previously been in the genus Cichlasoma, and De la Maza-Benignos \& LozanoVilano (2013) recently described three new species to complete the 12 currently recognized species. Recent phylogenetic studies have confirmed the monophyly of the genus but not of the species included in it (Hulsey et al., 2004; Concheiro-Pérez et al., 2007; Říčan et al., 2008; Říčan et al., 2013) because the two different haplotypes of $H$. labridens were recovered as polyphyletic. In addition, these works suggested the existence of two groups of species that were corroborated with the use of other molecular markers (Říčan et al., 2008; Mejía et al., 2012; Ríčan et al., 2013) and morphometric characters.

(De la Maza-Benignos \& Lozano-Vilano, 2013). One group of species was associated with $H$. cyanogutattus: $H$. cyanogutattus, $H$. deppii, $H$. minckleyi, $H$. carpintis, and $H$. tamasopoensis, and the other group was associated with $H$. bartoni: H. bartoni, H. steindachneri, H. pantostictus, $H$. labridens, $H$. pame, H. pratinus, and $H$. molango. Finally,

${ }^{1}$ Departamento de Zoología, Escuela Nacional de Ciencias Biológicas, Instituto Politécnico Nacional. Prolongación de Carpio y Plan de Ayala S/N, Colonia Casco de Santo Tomas, México, D.F., 11340, Mexico. (OM) hmejiag@ipn.mx (corresponding author); (FPM) monodactilo@hotmail.com; (YLR) yatzillleon@gmail.com; (ESG) egalera@ipn.mx

2Departamento de Biodiversidad y Sistemática, Instituto de Ecología, AC, Xalapa, Veracruz 91000 Mexico. efrain.deluna@inecol.edu.mx 
a recent DNA barcoding study that included samples of the complete geographic distribution of the $H$. bartoni species group (64 individuals from 22 localities) defined three wellsupported phylogenetic groups (León-Romero et al., 2012). Phylogenetic group I included haplotypes of $H$. bartoni and H. labridens from San Luis Potosí, phylogenetic group II included all of the haplotypes of $H$. steindachneri (the only species found to be monophyletic), and phylogenetic group III included haplotypes of $H$. pantostictus and $H$. labridens from the state of Hidalgo (León-Romero et al., 2012). All of the molecular studies mentioned above support the earlier suggestions of Taylor \& Miller (1983) and Miller et al. (2005) that $H$. labridens might comprise two different species. In fact, in the recent revision of the species performed by De la Maza-Benignos \& Lozano-Vilano (2013), they restrict the distribution of $H$. labridens to Laguna Media Luna and the headwaters of río Verde, San Luis Potosí, and describe three of the populations that were previously described as H. labridens as H. pratinus endemic to río el Salto, San Luis Potosí; H. pame (endemic to Rio Gallinas and its tributaries) and $H$. molango (endemic to Laguna Atezca in the state of Hidalgo Mexico) (Fig. 1). Nevertheless, in the geographic distribution of the $H$. bartoni species group, there are several localities that are currently identified as H. labridens (marked with a cross) that remain taxonomically uncertain. Moreover, though De la Maza-Benignos \& Lozano-Vilano (2013) consider the existence of diagnostic characters for each species, it is clear in their summary Tables 4 and 5 that there are several overlaps among the species for all of the characters that they analyzed. In this study, we performed a morphological revision of the Herichthys bartoni species group using meristic, morphometric, and geometric morphometrics data to assess the proposal of recently described species and the identity of uncertain populations. Following the proposal of Miller et al. (2005), we restricted the name of $H$. labridens to the populations of the headwaters of the río Verde, San Luis Potosí and referred to the rest of populations that are currently identified as $H$. labridens and included in phylogenetic group III, as defined by León-Romero et al. (2012), as $H$. cf. labridens, except for $H$. pame and $H$. molango, which were considered distinct species. Finally, we rejected the recent proposal of De la Maza-Benignos et al. (2014), who suggested that the species included in the H. labridens species group must be segregated into a new genus named Nosferatu because the morphological characters that support both genera are also present in species of the other genus (Pérez-Miranda et al. in prep.).

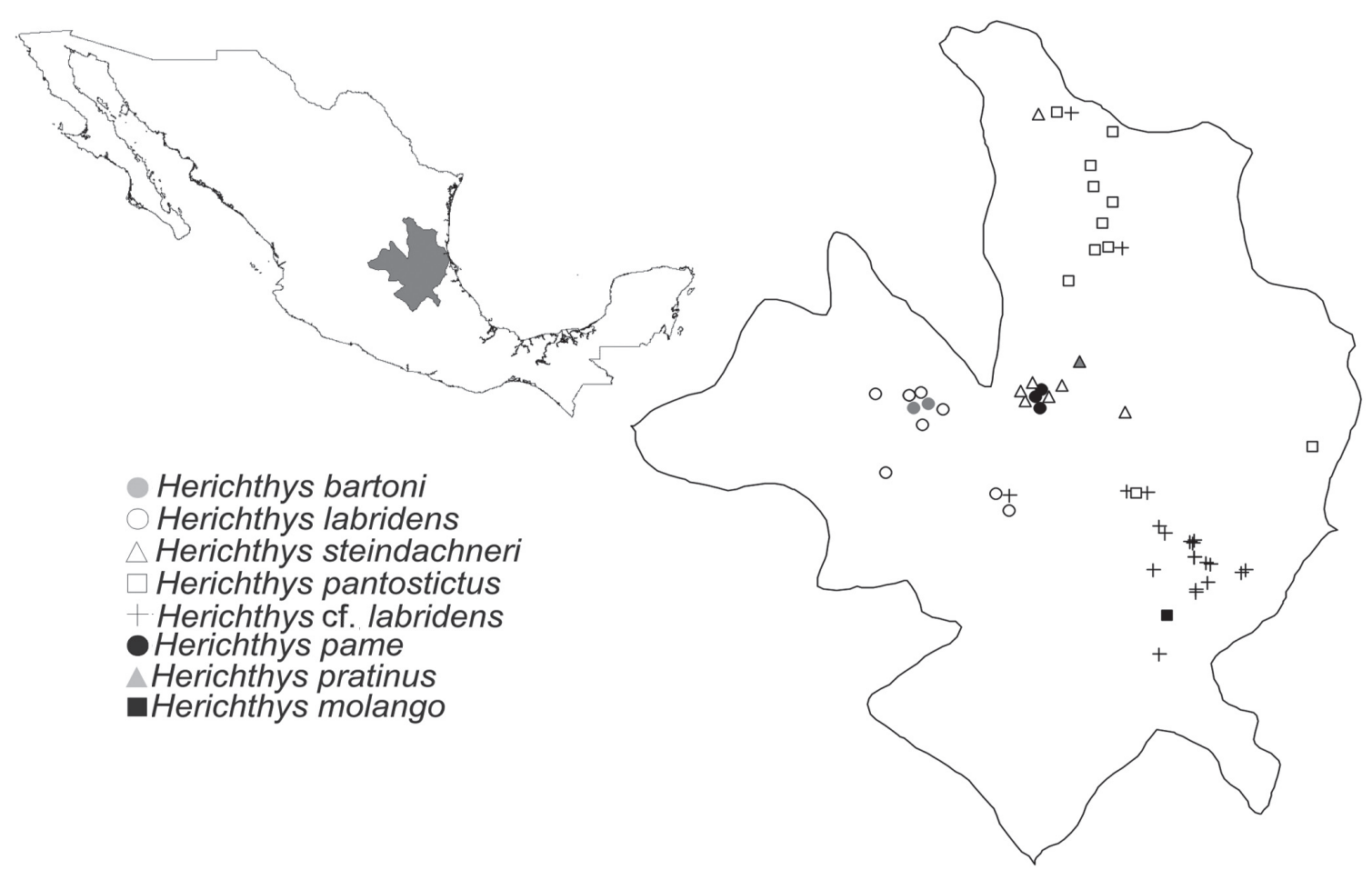

Fig. 1. Geographic distribution of the species included in the Herichthys bartoni group. Note: The species H. pratinus was not included in this work.

\section{Material and Methods}

The material consists of 544 individuals from 47 localities that were examined using meristical and traditional morphometrics analysis and 510 individuals from 48 localities that were examined using geometric morphometrics analysis (see Appendix). All specimens were identified using the diagnostic characters described by Taylor \& Miller (1983) and De la Maza-Benignos \& Lozano-Vilano (2013) and are deposited in the Colección 
Nacional de Peces Dulceacuícolas Mexicanos de la Escuela Nacional de Ciencias Biológicas (IPN-ENCB-P). In line with the information presented earlier (Miller et al., 2005; León-Romero et al., 2012; De la Maza-Benignos \& Lozano-Vilano, 2013), we include seven taxa: H. bartoni, H. labridens, H. steindachneri, H. pantostictus, H. pame, $H$. molango, and $H$. cf. labridens, however, we cannot include samples from $H$. pratinus.

Phylogenetic DNA barcoding updated. We generated the DNA barcodings for three individuals from $H$. pame to assign a phylogenetic position within the previously published tree of León-Romero et al. (2012). The parameters of the Bayesian analysis and the selected outgroups were the same as the previously published data. We were unable to incorporate individuals from $H$. molango because this species was formalin fixed and preserved.

Traditional morphometrics and meristic data. A total of 29 morphometric characters were measured in each individual using a digital caliper with a precision of 0.01 $\mathrm{mm}$ : total length (TLE), standard length (SLE), total length of the anal fin (LAF), total length of the dorsal fin (LDF), total length of the dorsal fin of spines (DFE), total length of the dorsal fin of rays (DFR), total length of the anal fin of spines (AFE), total length of the anal fin of rays (AFR), total length of the pectoral fin (LPF), total length of the pelvic fin (LVF), predorsal length (PDL), preanal length (PAL), postorbital length (POL), length of the upper maxilla (UML), length of the lower maxilla (LLM), length of the caudal peduncle (LCP), length of the dorsal fin at its base (LDB), length of the anal fin at its base (LAB), head length (HLE), snout length (SNL), length of the ascending premaxillary process (LPP), length of the post ascending premaxillary process (PPP), distance between the anal fin and the base of the pelvic fins (DBF), body height (BHE), head height at the eye (HHE), height of the caudal peduncle (HCP), eye diameter (EYD), height of the head at the preopercle (HHP), and intraocular distance (IOD). These morphometric data were standardized to remove the effects of size using two different approaches. The traditional approach used in fish taxonomy consists of estimating the proportions of each variable relative to the standard length (for all characters) or as a proportion of the head length (for characters related to this structure); however, this method can be used only if the growth is isometric. Thus, we used the Mossimann method (Butler \& Losos, 2002) to estimate the geometric mean of all variables to estimate the $\log$ (size) for use as an additional variable in statistical analysis. A total of 13 meristical characters were recorded for each specimen: number of spines in the dorsal fin, number of rays in the dorsal fin, number of spines in the anal fin, number of rays in the anal fin, number of rays in the pectoral fins, number of rays in the pelvic fins, number of gill rakers in the dorsal arm, number of gill rakers in the ventral arm, number of scales in a longitudinal series, number of circumpeduncular scales, number of scales in the first portion of the lateral line, number of scales in the second portion of the lateral line, and total number of scales in the lateral line. To compare our results with those previously published by De la Maza-Benignos \& Lozano-Vilano (2013), we performed a discriminant function analysis (DFA) for each data set in Statistica 10 (Statsoft Inc.). Additionally, a multidimensional scaling analysis (MDS) was performed for each data set using Euclidean distances, as suggested by McMahan et al. (2011). This test was considered informative if the stress level was lower than 0.15 . All analyses were performed in PAST 3.01 (Hammer, Harper \& Ryan, 2001). Finally, to identify significant differences among the seven taxa, a one-way ANOVA was conducted on the morphometric data adjusted by proportions, and an ANCOVA was conducted on the morphometric data adjusted using the Mossimann method, with the logsize variable serving as the covariate. In both cases, Tukey's multiple comparison test was used to identify significant differences among taxa in Statistica 10. Conversely, to identify significant differences among the 13 recorded meristic characters, a Kruskal-Wallis analysis using a multiple comparisons of the mean ranks test was performed and implemented in Statistica 10.

Geometric morphometrics. Each specimen was photographed in the left view, and 25 landmarks were digitized for the body, as was a subsample of 15 landmarks of the head, in accordance with Trapani (2003) and Genner et al. (2007) in tpsdig (Rohlf, 2010) (Fig. 2). To eliminate the effect of curvature caused by the preservation method, we performed a regression with the "unbend specimens" option in the tpsutil software (Rohlf, 2012). For the body, we used four landmarks (2, 9,18 , and 20), and for the head, we used three landmarks (2, 18, and 19). The Bookstein coordinates generated were converted to Procrustes distances using CoordGen 6 , which was included in the program IMP (Sheets et al., 2001). To eliminate the allometric effect associated with growth, we performed a multivariate regression analysis using the Procrustes distances as the dependent variable and the size of the centroid as the independent variable. The adjusted Procrustes distances were used as descriptors of the level of differences among body and head shapes between the groups; the significance of the differences was evaluated using a permutation test with 10,000 iterations (Elmer et al., 2010) in MorphoJ 1.03C (Klingenberg, 2011). Finally, the residuals of the regression analysis were used in a canonical analysis to compare the seven groups. Similar to the Procrustes distances, the significance of the differences was evaluated using a permutation test with 10,000 iterations in MorphoJ 1.03C (Klingenberg, 2011). 


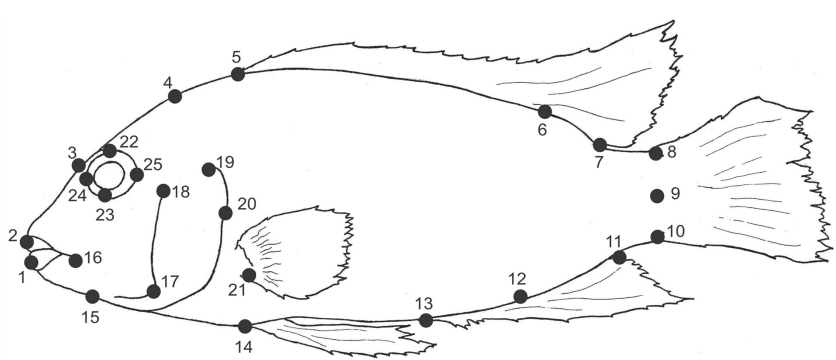

Fig. 2. Landmarks recorded in this study. 1. Anterior end of the lower maxilla 2. Anterior end of the upper maxilla 3. Length of the ascending premaxillary process 4 . End of the supraoccipital bone 5. Start of the dorsal fin 6. Last spine of the dorsal fin 7. End of the dorsal fin 8. Upper boundary of the caudal fin 9. Center of the caudal fin 10. Base of the caudal fin 11. End of the anal fin 12. Last spine of the anal fin 13. Origin of the anal fin 14. Origin of the pelvic fin 15. Posterior end of the lower maxilla 16. Posterior end of the upper lip 17. Maximum point of curvature at the preoperculum 18. Upper end of the preoperculum 19. Upper end of the operculum 20. Most posterior end at the operculum 21. Origin of the pectoral fin 22. Upper extreme of the sphenotic orbit 23. Base of the sphenotic orbit 24. Left extreme of the sphenotic orbit 25. Right extreme of the sphenotic orbit.

\section{Results}

DNA barcoding. The phylogenetic analysis of the mitochondrial COI confirms the previously published results using COI and other molecular markers that the genus Herichthys comprises a well-supported monophyletic group $(\mathrm{BPP}=1.0)$ and that this genus includes two well-supported clades: the group of species related to $H$. cyanoguttatus $(\mathrm{BPP}=1.0)$ and the group of species related to $H$. bartoni analyzed in this study $(\mathrm{BPP}=1.0)$. Contrary to the previously published results (León-Romero et al., 2012), none of the species included in the $H$. bartoni species group was recovered as monophyletic, due to the unexpected inclusion of the haplotypes of $H$. pame in the clade of H. steindachneri (Fig. 3). However, three well-supported phylogenetic groups $(\mathrm{BPP}=1.0)$ were recovered, each including a species that had previously been identified as $H$. labridens. Phylogenetic group I includes $H$. bartoni and $H$. labridens, phylogenetic group II includes $H$. steindachneri and $H$. pame and finally, phylogenetic group III includes $H$. pantostictus and the individuals considered in this study as $H$. cf. labridens, which we synonymize into $H$. molango (see below).

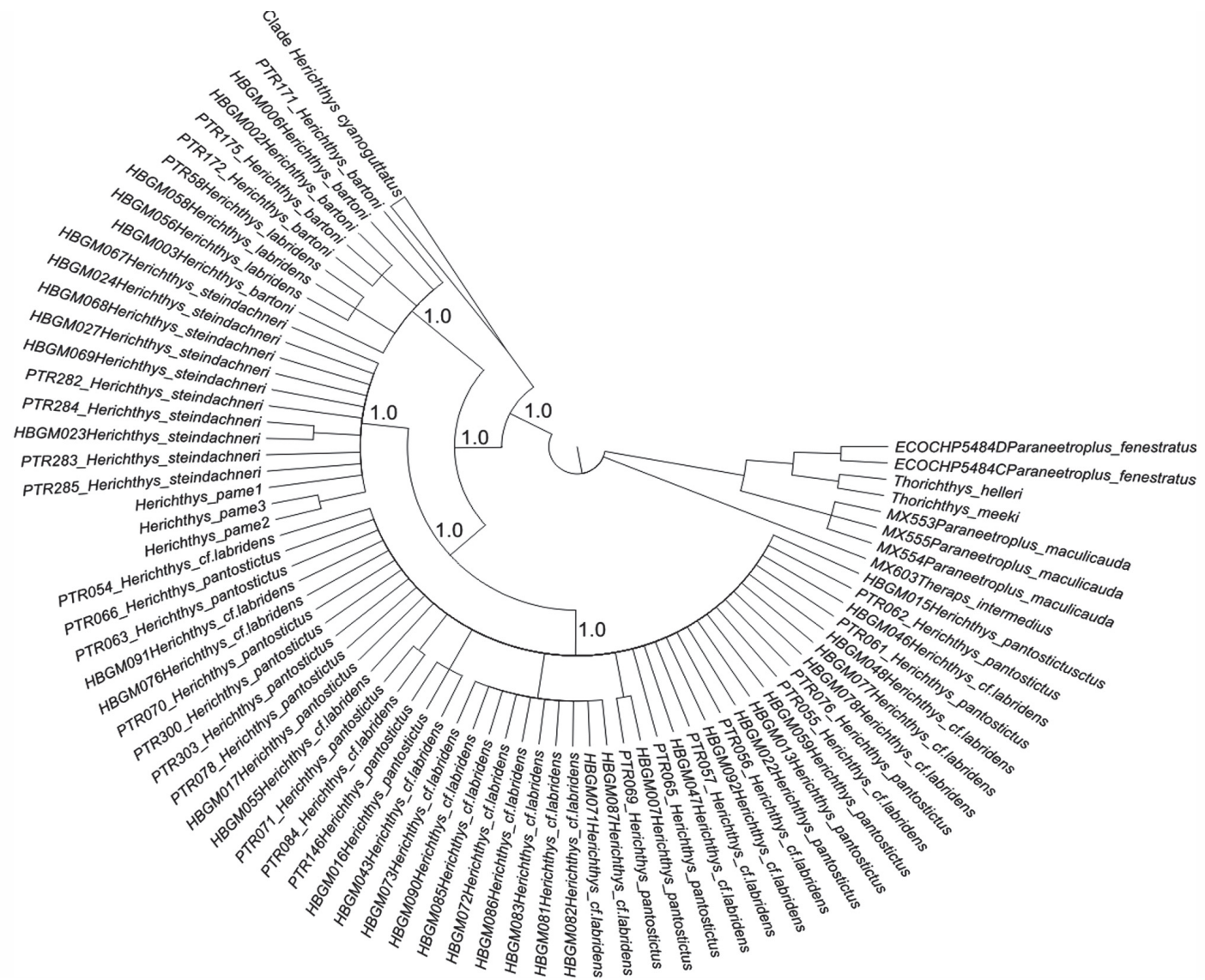

Fig. 3. Phylogenetic analysis of the Herichthys bartoni species group obtained from the Bayesian analysis of an approximately $652 \mathrm{bp}$ fragment of the mitochondrial cytochrome c oxidase subunit I (DNA Barcode). Numbers above nodes are the Bayesian Posterior Probabilities (BPP) for the principal clades recovered in the analysis. The haplotypes of the species included in the $H$. cyanoguttatus species group were collapsed to facilitate representation. 
Traditional morphometric and meristic data. The canonical variance analysis of the species included in the Herichthys bartoni species group partially differentiated among $H$. bartoni, $H$. pantostictus, and $H$. steindachneri for the three data sets analyzed (Fig. 4); however, the other four species that were previously described as $H$. labridens were hardly separated. These results were confirmed by the classification matrix for the discriminant function analysis (Table 1). Although the percentage of corrected classification for the meristic data in $H$. pantostictus was only $30.23 \%$, this species is clearly separated from the others when the morphometric data are adjusted as proportions (81.39\%). Conversely, nearly of the $50 \%$ of individuals of $H$. steindachneri were correctly classified by the meristic data and the morphometric data adjusted as proportions. Finally, almost $90 \%$ of the $H$. bartoni individuals were correctly classified in the three data sets. These results contrast greatly with those found for the other four species. Almost $65 \%$ of the individuals classified as $H$. labridens from the Media Luna and río Verde were successfully classified; this value dropped to $40 \%$ for $H$. molango when the data were adjusted as proportions, as most of the individuals were classified as $H$. cf. labridens (data not shown). It further dropped to only $5 \%$ for data that were adjusted using the Mossimann method for $H$. pame, in which most of the individuals were classified as H. labridens (data not shown). Finally, though it is a widely distributed species, more than $90 \%$ of the individuals classified as $H$. cf. labridens $(=H$. molango) were correctly classified. However, none of the multidimensional scaling analysis performed showed significant differences because the levels of the stress in the test ranged from 1.415 for the Mossimann adjusted data to 1.471 for the meristic data (data not shown). The ANOVA revealed that $H$. bartoni differs from the rest of the species in six of the characters that are adjusted as proportions (total length of the anal fin (LAF), total length of the dorsal fin of spines (DFE), total length of the anal fin of rays (AFR), preanal length (PAL), length of the anal fin at its base (LAB) and intraocular distance (IOD)), H. molango differs from the rest of the species in three characters (total length of the anal fin (LAF), total length of the dorsal fin (LDF) and snout length (SNL)) and $H$. pantostictus differs from the rest of the species in four characters (length of the post ascending premaxillary process (PPP), head height at the eye (HHE), eye diameter (EYD) and height of the head at the preopercle (HHP)) (Table S1). Meanwhile, in the ANCOVA for the data adjusted using the Mossimann method, H. bartoni differs from the rest of the species in the postorbital length (POL), H. labridens differs from the rest of the species in the standard length (SLE), height of the head at the preopercle (HHP) and intraocular distance (IOD) and $H$. pame differs from the rest of the species in the total length (TLE), standard length (SLE), total length of the dorsal fin (LDF), total length of the dorsal fin of spines (DFE), predorsal length (PDL), preanal length (PAL), length of the caudal peduncle (LCP), length of the ascending premaxillary process (LPP) and length of the post ascending premaxillary process (PPP) (Table S2). Finally, according to the Kruskal-Wallis $\mathrm{H}$ test, only $H$. bartoni differs from the rest of the species in number of spines in the dorsal fin, number of spines in the anal fin, and number of rays in the pectoral fins (Table S3). Nevertheless, despite the results of the statistical analysis, a close inspection to the minimum and maximum values in Tables S1 to S3 indicates that all of the characters analyzed showed overlapping values that prevented the proposal of diagnostic characters that would allow us to distinguish any species.

Geometric morphometrics. The analysis of Procrustes distances revealed that the seven taxa differ significantly in the shape of the body, but only half of the paired comparisons were significant for the shape of the head (Table 2). Both analysis revealed that the greatest difference in shapes occurs between $H$. pame and $H$. molango $(\mathrm{d}=0.0969, P<0.05$ for the shape of the head; $\mathrm{d}=0.0635, P<0.05$ for the shape of the body), while the smallest difference exists between $H$. labridens and $H$. cf. labridens $(\mathrm{d}=0.0176, P<0.05$ for the shape of the head; $\mathrm{d}=0.0126, P<0.05$ for the shape of the body) (Table 2). Conversely, the canonical analysis of the seven groups failed to reveal a clear pattern in the morphospace for the shape of the head (Fig. 5A-B), but the canonical analysis for the shape of the body allows the separation of $H$. bartoni and $H$. pame from the rest of the species (Fig. 5C-D).

If we compare the pairs of species included in each of the phylogenetic groups derived from the DNA barcoding analysis, we can observe that within phylogenetic group I, $H$. bartoni (blue dots) and H. labridens (green dots) have different body shapes. Similar results were found when we compared H. steindachneri (brown dots) with H. pame (black dots). However, H. pantostictus (gray dots), H. cf. labridens (red dots), and H. molango (violet dots) were barely separated, and a null separation occurred between $H$. cf. labridens and $H$. molango. This information, coupled with the absence of diagnostic characters, led us to state that the populations included in this study as $H$. cf. labridens and $H$. molango comprise a single widely distributed species, a result similar to that found recently by McMahan et al. (2011) that led them to synonymize Paraneetroplus synspilus into P. melanurus and led us to synonymize Herichthys cf. labridens into $H$. molango.

\section{Herichthys bartoni (Bean, 1892)}

Acara bartoni Bean, 1892: 286-287 [original description].

Cichlasoma bartoni. -Meek, 1904: 211-212 [description]. -Miller, 197620 [citation]. -Taylor \& Miller, 1983: 1-15 [citation]. -Miller et al., 2005: 299 [catalog].

Cichlosoma bartoni. -Regan, 1905: 445 [citation].

Herichthys bartoni. -León-Romero et al., 2012: 1021-1026 [phylogenetic analysis]. -De la Maza-Benignos \& LozanoVilano, 2013: 119-120 [description].

Nosferatu bartoni. -De la Maza-Benignos et al., 2014: in press [citation]. 

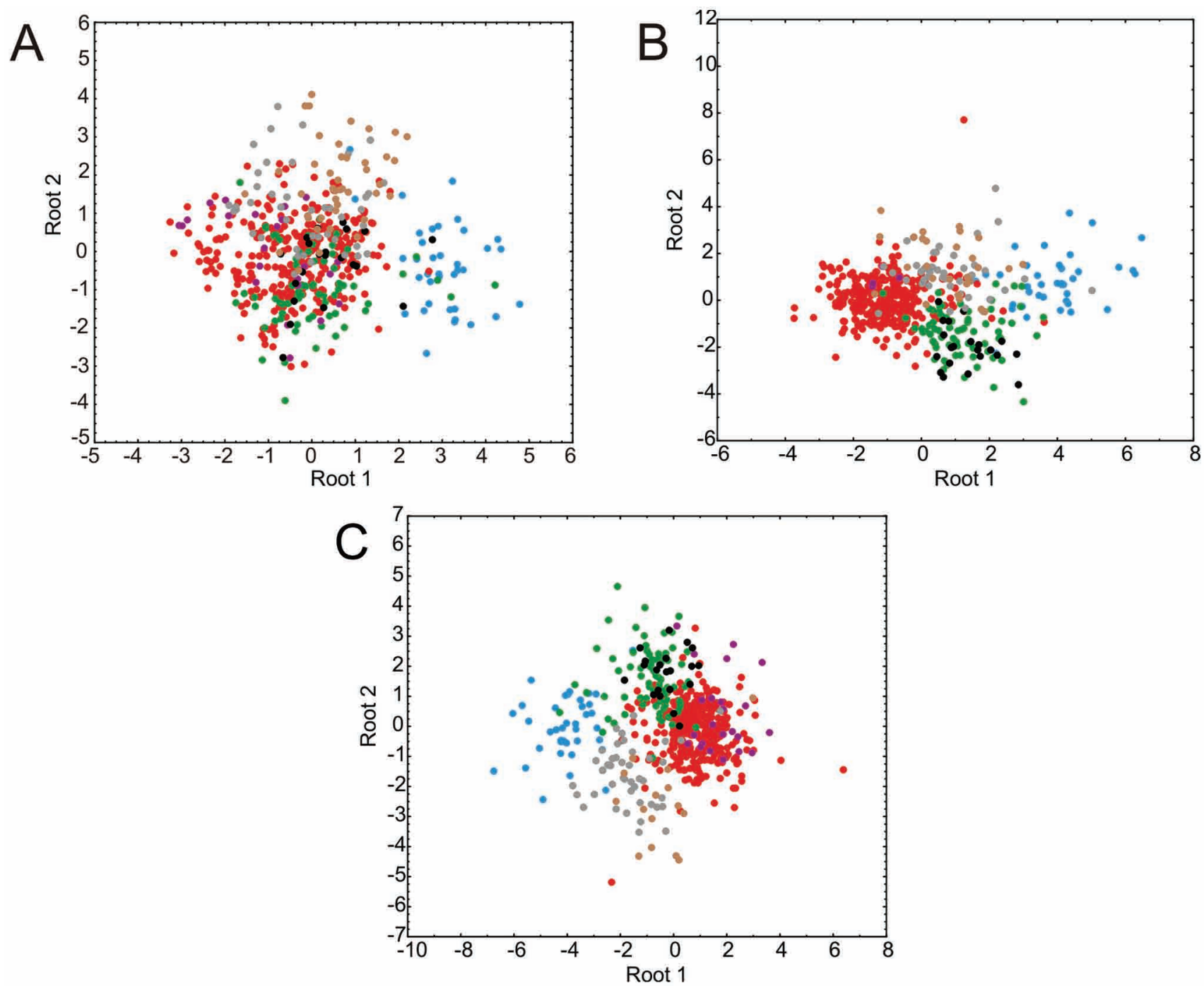

Fig. 4. Canonical variance analysis derived from the discriminant function analysis of the species included in the Herichthys bartoni species group. A) Meristic data B) Morphometric data adjusted by the method of Mossimann C) Morphometric data adjusted as proportions. Symbology: Blue: H. bartoni, Red: H. cf. labridens, Green: H. labridens, Violet: H. molango, Black: H. pame, Gray: H. pantostictus, Brown: H. steindachneri.

Table 1. Matrix of classification for the seven species of the Herichthys bartoni species group derived from the Discriminant Function Analysis (DFA). The data are presented as percents of correct classification for each data set.

\begin{tabular}{cccc}
\hline Species & Meristic & Mossimann & Proportions \\
\hline H. bartoni & 92,1053 & 86,8421 & 87,1795 \\
H. cf. labridens & 92,8571 & 93,8111 & 93,8312 \\
H. labridens & 20,5480 & 64,3836 & 65,7534 \\
H. molango & 0,0000 & 0,0000 & 39,1304 \\
H. pame & 0,0000 & 4,7619 & 0,0000 \\
H. pantostictum & 30,2326 & 67,4419 & 81,3954 \\
H. steindachneri & 50,0000 & 29,6296 & 46,6667 \\
Total & 67,5183 & 79,1423 & 80,8429 \\
\hline
\end{tabular}

Diagnosis. Herichthys bartoni can be distinguished from the rest of the species included in the H. labridens species group by a black-and-white to light gray coloration in live adult specimens.

Description. Morphometric and meristic data are summarized in Tables 3-4.

Color in life. Body white to light gray, with a series of blotches that extend from the opercle to the basis of the caudal fin. Dots in the head absent, with a red to purple axil mark at the pectoral fins.

Color in alcohol. Body dark brown to dark gray with black blotches, fins turn yellow to light brown.

Distribution. Laguna de la Media Luna and río Verde. 
Table 2. Procrustes distances among the seven taxa of the the Herichthys bartoni species group included in this study. Above the diagonal the results for the 15 landmarks of the head, below the diagonal the results for the 25 landmarks of the body. ${ }^{*}$ denotes significant $\mathrm{p}$ values $(\mathrm{p}<0.05)$ after 10,000 iterations.

\begin{tabular}{|c|c|c|c|c|c|c|c|}
\hline & H. bartoni & H. labridens & H. steindachneri & H. cf. labridens & H. pantostictus & H. pame & H. molango \\
\hline H. bartoni & & $0.041^{*}$ & $0.0489 *$ & $0.0355^{*}$ & $0.0552 *$ & $0.0602 *$ & 0,0624 \\
\hline H. labridens & $0.0337 *$ & & 0,0232 & $0.0176^{*}$ & $0.0430 *$ & 0,0406 & 0,0783 \\
\hline H. steindachneri & $0.0394 *$ & $0.0236^{*}$ & & $0.0250 *$ & 0,0433 & $*$ & 0,0771 \\
\hline H. cf. labridens & $0.0348 *$ & $0.0126^{*}$ & $0.0227^{*}$ & & $0.0552 *$ & $0.0602 *$ & 0,0624 \\
\hline H. pantostictus & $0.0380 *$ & $0.0162 *$ & $0.0212 *$ & $0.013 *$ & & $0.0615^{*}$ & $0.0947 *$ \\
\hline H. pame & $0.047^{*}$ & $0.0488^{*}$ & $0.0585^{*}$ & $0.0485^{*}$ & $0.0526^{*}$ & & $0.0969 *$ \\
\hline H. molango & $0.0603 *$ & $0.0393^{*}$ & $0.0414 *$ & $0.0421^{*}$ & $0.0424 *$ & $0.0635^{*}$ & \\
\hline
\end{tabular}
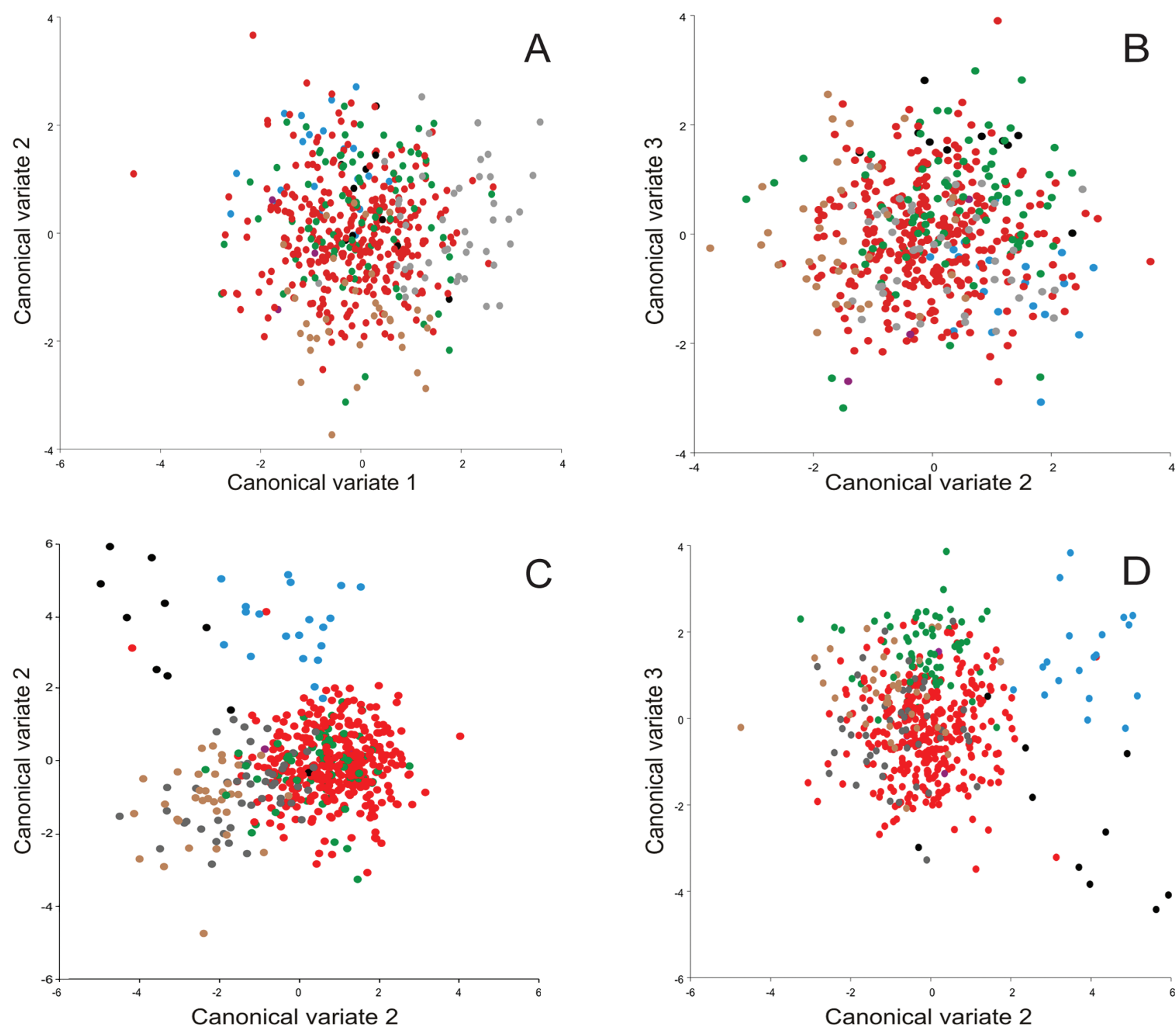

Fig. 5. Canonical variance analysis derived from the geometric morphometric analysis of the species included in the Herichthys bartoni species group. A) canonical variate 1 and 2 for the head, B) canonical variate 2 and 3 for the head, C) canonical variate 1 and 2 for the body, D) canonical variate 2 and 3 for the body. Symbology: Blue: H. bartoni, Red: $H$. cf. labridens, Green: H. labridens, Violet: H. molango, Black: H. pame, Gray: H. pantostictus, Brown: H. steindachneri. 
Remarks. Herichthys bartoni was described originally by Bean (1892) as Acara bartoni with four specimens from Hauzteca Potosina (= Huasteca Potosina). Bean states that the height of the body is contained 2.3 times in the standard length, the eye diameter is contained 4.5 to 5.5 times in the length of the head and twice in the length of the snout, the intraocular distance is $66 \%$ of the snout length and the length of the upper maxilla is $40 \%$ of the head length. These proportions are similar to those found in this study (2.2 to 2.7 times the height of the body, 3.1 to 5.1 and 0.81 to 2.0 for the eye diameter and $63 \%$ to $127 \%$ for the intraocular distance). The only exception was the $12 \%$ to $28 \%$ of the upper maxilla compared with the head length; in fact, none of the specimens reviewed in this study reached such proportions (the highest value was for one specimen of $H$. molango $35 \%$ ), so we think that the Bean (1892) measurement was taken to the end of the maxillary bone and not to the joint with the lower maxilla, as we measured. Nevertheless, at least one of the specimens reviewed by Bean (1892) corresponded to a different species. Bean states that "In a specimen about 5 inches the cheeks and snout are profusely covered with minute roundish brown dots", a character present in other species of the group but not in $H$. bartoni. The same situation seems to be true for the material described by Meek (1904). As noted by De la Maza-Benignos \& Lozano-Vilano (2013) and Meek (1904) states that the sides of the head are covered with small dark dots but that in the eight specimens reviewed by Meek (1904), the number of anal spines was $\mathrm{V}$, a trait observed in only $15 \%$ of the specimens of $H$. bartoni reviewed in this study. It is thus likely that the material reviewed by Bean (1892) and Meek (1904) could correspond to other species distributed in the Huasteca Potosina, such as $H$. pame or $H$. steindachneri, but not to $H$. labridens because the latter species lacks the dots on the head that occur on H. bartoni.

Material examined. Mexico: [Laguna de la Media Luna, SLP] ENCB-P P3880 (n=19) 57.6 to $111.6 \mathrm{~mm} \mathrm{SL}$; [Manantial los Anteojos, Río Verde, SLP] ENCB-P P6108 (n=20) 54.0 to $118.8 \mathrm{~mm} \mathrm{SL.}$

\section{Herichthys labridens (Pellegrin, 1903)}

Heros labridens Pellegrin, 1903: 122-123 [original description]. Cichlasoma bartoni. -Meek, 1904: 211-212 [description].

Cichlosoma labridens. -Regan, 1905: 443 [citation]. -Miller, 1976:

20 [citation]. -Taylor \& Miller, 1983: 1-20 [citation]. -Miller et al., 2005: 401 [catalog].

Herichthys labridens. -León-Romero et al., 2012: 1021-1026 [phylogenetic analysis].- De la Maza-Benignos \& LozanoVilano, 2013: 103-106 [redescription].

Nosferatu labridens. -De la Maza-Benignos et al., 2014: in press [citation].

Diagnosis. There are no unique autapomorphies that allow us to distinguish Herichthys labridens from the rest of the species of the group. However, this species could be distinguished from the sympatric species $H$. bartoni by its yellow to golden coloration in life and from the rest of the species of the ensemble by the absence of dots on the head.

Description. Morphometric and meristic data are summarized in Tables 3-4.

Color in life. Body yellow to golden that vanishes to the ventral region, five to six black blotches that extend from the half of the body to the caudal fin, red to purple axil mark present.

Color in alcohol. Body brown to reddish-brown, darker at the base of the dorsal fin. Fins turn to brown or gray, blotches and axil mark could disappear.

Distribution. Laguna de la Media Luna, río Verde and río Calabazas, San Luis Potosí, río Jalpan, and río Conca, Querétaro and río Manzanares, Guanajuato.

Remarks. There is apparent confusion regarding the type locality of this species. According to De la Maza-Benignos \& Lozano-Vilano (2013) (but see also Taylor \& Miller 1983) and Pellegrin (1903) states that the type locality was "Huazteca Potosina", Guanajuato. The confusion arises because Prof. Alfredo Dugès shipped the material to Pellegrin from the city of Guanajuato. Nevertheless, there is no reason for confusion - Pellegrin (1903:122) clearly states that the material comes from Huasteca Potosina (Mexique) (not Huazteca, as suggested by De la Maza-Benignos \& Lozano-Vilano 2013); we believe that the suggestion of De la Maza-Benignos \& Lozano-Vilano (2013) comes from the information available in the work of Taylor \& Miller (1983), and that they not review the original description performed by Pellegrin (1903). In the same manner, De la Maza-Benignos \& Lozano-Vilano (2013) wrongly interpret the work of Regan (1905) (and not 1906-1908, as they state) and suggest that Regan includes accounts from three different species. First, Regan (1905) sets the eye diameter at 4-5.5 and the interorbital distance at 3 (both in HL); dorsal fin XV-XVI, 10-12 and anal fin V-VI, 8-9. These values fell within the range observed in this study (eye diameter 3.24-5.21; interorbital distance 2.15-3.46; dorsal fin XIV-XVII, 10-13 and anal fin IV-VI, 8-11), and the eight specimens reviewed by Regan (1905) come from río Verde that includes the native distribution of this species.

Material examined. Mexico: [Laguna de la Media Luna, SLP.] ENCB-P P1891, 5, 87.0-122.1 mm SL; río Verde, SLP. ENCB-P P3770, 11, 71.4-145.7 mm SL, río Jalpan, Qro. ENCB-P P4866, 6, 64.0-116.4 mm SL, río Conca, Qro. ENCB-P P5041, 20, 57.6-111.6 mm SL, río Manzanares, Gto. ENCB-P P5061, 18, 64.7-143.8 mm SL, Canal de la Media Luna, SLP. ENCB-P P6011, 3, 70.8-80.1 mm SL, río Verde, SLP. ENCB-P P6012, 2, 92.1-96.5 mm SL, río Calabazas, SLP. ENCB-P P6016, 8, 97.0-152.1 mm SL. 


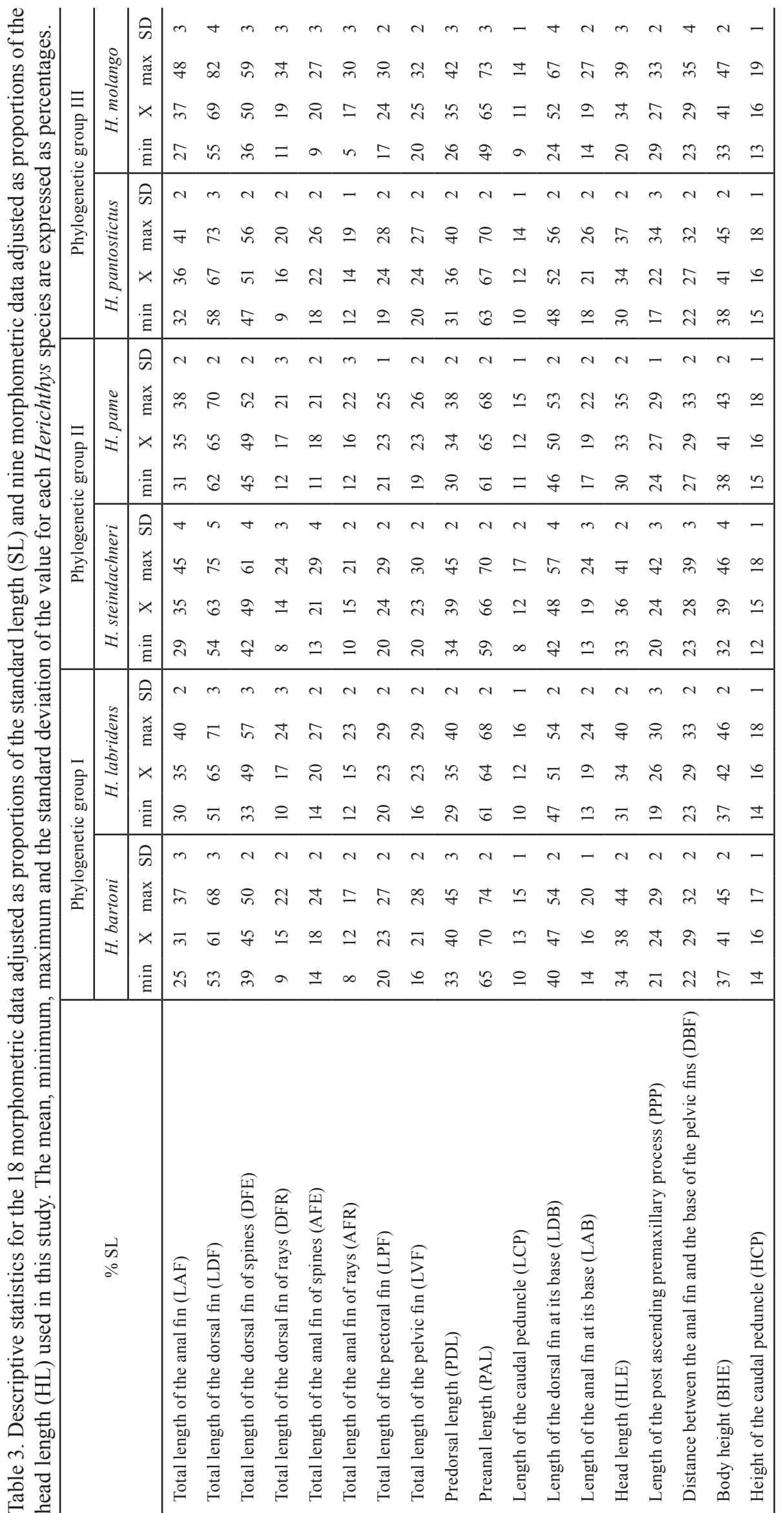

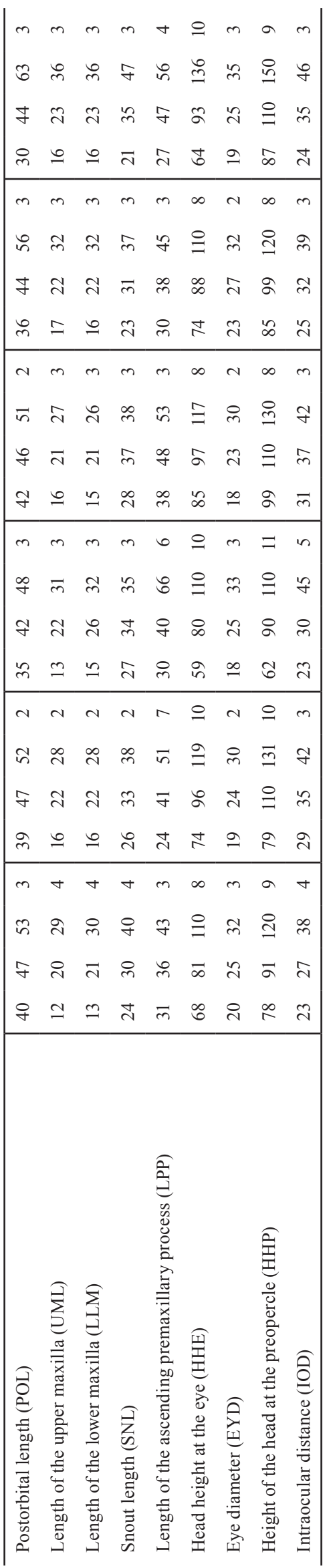




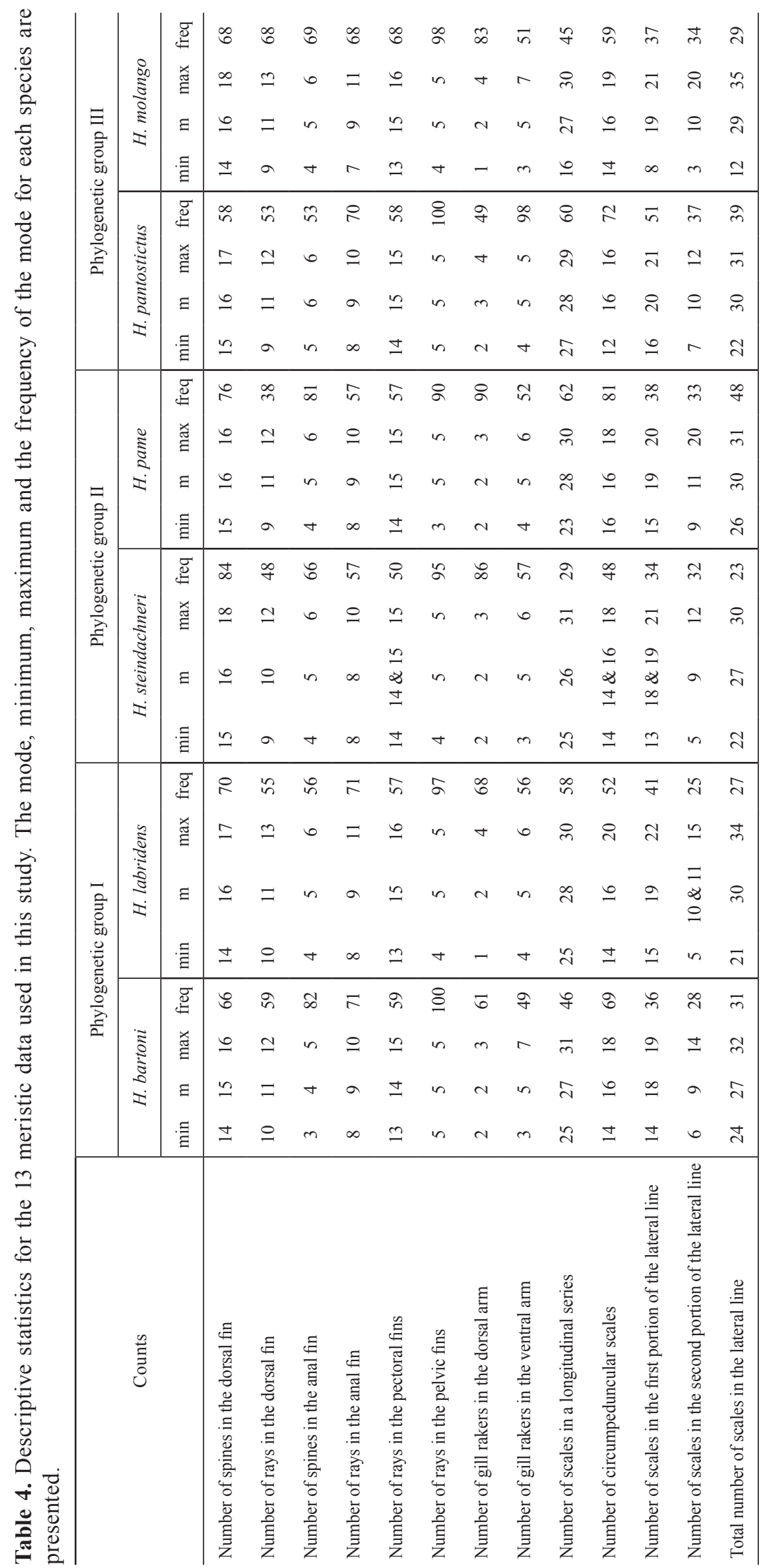




\section{Herichthys steindachneri (Jordan \& Snyder, 1899)}

Cichlasoma steindachneri Jordan \& Snyder, 1899: 143-144 [original description]. -Regan, 1905: 444-445 [redescription]. -Miller, 1976: 20 [citation]. -Taylor \& Miller, 1983: 1-6 [citation]. -Miller et al., 2005: 403-404 [catalog].

Herichthys steindachneri. -León-Romero et al., 2012: 1021-1026 [phylogenetic analysis]. -De la Maza-Benignos \& LozanoVilano, 2013: 117-119 [redescription].

Nosferatu steindachneri. -De la Maza-Benignos et al., 2014: in press [citation].

Diagnosis. Herichthys steindachneri could be distinguished from the rest of the species of the group by its long head, which ranges from $89.6 \%$ to $113.2 \%$, in comparison with the body height at the basis of the pelvic fins.

Description. Morphometric and meristic data are summarized in Tables 3-4.

Color in life. Body greenish-gray, darker in the dorsal to almost white in the ventral region; a series of blotches that extend from the posterior end of the eye to the basis of the caudal fin, blotches in the second half of the body could form up to six bars. Brown or black dots in the head up to basis of the pectoral fins but not in the dorsal fin, fins yellowish to green, dorsal, anal and caudal usually with a brown or black blotch at its base; red to purple axil mark present.

Color in alcohol. Body dark gray to light brown, lighter at the ventral region, with one series of black blotches, fins turn whitish, axial mark could disappear.

Distribution. Río Gallinas and its tributaries. There are historical records of its presence in El Pujal and El Rodeo San Luis Potosí and in Villa Aldama and Jaumave, Tamaulipas.

Remarks. In the recent redescription of the species, De la Maza-Benignos \& Lozano-Vilano (2013) state that this species could be distinguished from the rest of the species by having the lower jaw extending the upper jaw (prognathous), whereas the opposite condition, jaws of equal size, are rare and present mostly in juveniles. In the specimens that we analyzed, the proportion of lower/upper maxilla (prognathous) was barely 1.03; this condition was present in $54 \%$ of the specimens, with no relationship to size $(51 \mathrm{~mm}$ to $155 \mathrm{~mm}$ ). Jaws of equal size were present in $46 \%$ of the individuals and ranged from $48 \mathrm{~mm}$ to $150 \mathrm{~mm}$ in standard length; because of this, we rejected the use of this trait as a diagnostic characteristic. Conversely, De la Maza-Benignos \& Lozano-Vilano (2013) suggest that the descriptions of Jordan \& Snyder (1900) and Meek (1904) were based on a composite of $H$. steindachneri and $H$. pame. The proportions found by Jordan \& Snyder (1900) were similar to those found by us. Nevertheless, we found 5 to 9 gill rakers, while in the original description of $H$. steindachneri, Jordan \& Snyder (1900) found 10, a value similar to that found in $H$. pame (9-11) by De la MazaBenignos \& Lozano-Vilano (2013). Meek (1904) description includes $\mathrm{V}$ anal spines, seven anal rays and an upper jaw that is slightly longer than the lower. The extreme low number of anal rays (7) reported by Meek (1904) was found only in a single specimen of $H$. molango $(=H$. cf. labridens) reviewed in this study, and an upper jaw slightly longer than the lower was only found in $H$. pame (lower jaw/upper jaw proportion $=0.98$ ). For the former, we concur with De la Maza-Benignos \& Lozano-Vilano (2013) proposal that the descriptions of Jordan \& Snyder (1900) and Meek (1904) included two different species. Contrary to that stated earlier, the geographic distribution of this species includes not only río Gallinas but also its tributaries, río Tamasopo, río Agua Buena, and río Ojo Frío in San Luis Potosí. We have historical records of this species in El Pujal and El Rodeo, the municipality of Río Verde, San Luis Potosí and Villa Aldama and Jaumave, Tamaulipas. We claim that these specimens were correctly identified. According to Miller et al. (2005), H. steindachneri could be distinguished from the rest of the species by a long head that is usually greater than the body height at the pelvic fin basis. In the specimens analyzed in this study, the proportion of the head ranges from $89.6 \%$ to $113.2 \%$ ( $X=96.3 \%$ ); this proportion was similar in Jaumave, ranging from $91.5 \%$ to $102 \%$ ( $X=94.6 \%)$ and Villa Aldama $93.6 \%$ to $95.5 \%(X=94.7 \%)$ specimens. The head of H. steindachneri is not longer as Miller et al. (2005) suggested, but it is larger than the head observed in other species. For example, in $H$. pame this proportion ranges from $75.3 \%$ to $86.1 \%$ ( $\mathrm{X}=81.4 \%$ ), but only in the specimens of $H$. cf. labridens $(=H$. molango) from Jaumave does this value range from $79.5 \%$ to $85.6 \%$ ( $\mathrm{X}=83.3 \%$ ), so there is no chance to confuse the two species.

Material examined. Mexico: El Pujal, SLP. ENCB-P P82, 11, 66.9-155.8 mm SL, Ciénega cerca de Jaumave, Tamps. ENCB-P P1742, 9, 48.0-102.84 mm SL, Tamasopo, SLP. ENCB-P P3898, 1, $126.4 \mathrm{~mm}$ SL, El Rodeo, municipality of Río Verde. ENCB-P P4823, 1, 73.3 mm SL, [Agua Buena, SLP. ENCB-P P4876, 1, 65.0 mm SL, Cascadas de Tamasopo, SLP. ENCB-P P6010, 7, 62.098.1 mm SL, río Gallinas, SLP. ENCB-P P6111, 4, 54.2-94.1 mm SL, río Tamasopo, SLP. ENCB-P P6114, 10, 51.6-110.2 mm SL.

\section{Herichthys pame De la Maza-Benignos \& Lozano- Vilano, 2013}

Herichthys pame De la Maza-Benignos \& Lozano-Vilano, 2013: 112-114 [original description].

Nosferatu pame. -De la Maza-Benignos et al., 2014: in press [citation].

Diagnosis. There are no unique autapomorphies that allow us to distinguish Herichthys pame from the rest of 
the species of the group. Similar to H. steindachneri, the blotches of the body usually extend to the opercle and to the posterior end of the eye, while in the other species, the blotches do not extend beyond the opercle. This species could be distinguished from it sympatric species $H$. steindachneri by a small head, which reaches at most $86 \%$ of the length in comparison with the height at the basis of the pelvic fins, in contrast with $H$. steindachneri, in which this proportion is greater than $89.6 \%$.

Description. Morphometric and meristic data are summarized in Tables 3-4.

Color in life. Body yellow to light brown, sometimes green, darker in the dorsal that vanishes to almost white in the ventral region. Dark blotches that extend from the end of the eye to the caudal fin, blotches in the second half of the body could form four to seven vertical bars, head with brown or black dots that does not extend beyond the pectoral fins, pectoral and pelvic fins yellow, while caudal and anal fin usually light brown or red, in some specimens the dorsal, caudal and anal fin with speckled, red to purple axil mark present.

Color in alcohol. Body gray to light brown, vanishing to yellow or white to the ventral region, fins turn whitish, in some specimens, margin of the dorsal fin turn black, axial mark could disappear.

Distribution. Endemic of río Gallinas and its tributaries.

Remarks. According to the original description, this species could be separated from the other species of the genus by a small eye diameter (mean $23 \%$, SD $1 \%$ ) and a long snout (mean 39\%, SD 2\%), among other traits. Our results indicated that none of these characters could be diagnostic because a small eye diameter is also present in H. molango and a long snout is also present in both $H$. pantostictus and $H$. molango. Nevertheless, this species is clearly separated from the rest in the canonical variable analysis derived from the analysis of geometric morphometrics of body shape (Fig. 5 ). Herichthys pame was originally considered a geographic variant of $H$. labridens by Taylor \& Miller (1983, Fig. 4), although Miller et al. (2005) later reconsidered and state that this species represents an undescribed species. Although De la Maza-Benignos \& Lozano-Vilano (2013) state that this species was recovered as a sister taxon of $H$. steindachneri by Hulsey et al. (2004), the DNA barcoding analysis performed in this study indicates that both species share some haplotypes and were undistinguished.

Material examined. Mexico: Cascadas de Tamasopo, SLP. ENCB-P P4758, 11, 88.3-141.2 mm SL, Cascadas de Tamasopo, SLP. ENCB-P P6371, 5, 64.6-101.5 mm SL, Puente El Ahogado, SLP. ENCB-P P6372, 5, 62.4-121.8 mm SL.

\section{Herichthys pantostictus (Taylor \& Miller, 1983)}

Cichlasoma pantostictus Taylor \& Miller, 1983: 1-24 [original description]. -Miller et al., 2005: 402-403 [catalog].

Herichthys pantostictus. -León-Romero et al., 2012: 1021-1026 [phylogenetic analysis].

De la Maza-Benignos \& Lozano-Vilano, 2013: 117-119 [redescription].

Nosferatu pantostictus. -De la Maza-Benignos et al., 2014: in press [citation].

Diagnosis. There are no unique autapomorphies that allow us to distinguish Herichthys pantostictus from the rest of the species in the group. Most of the specimens of this species showed brown to black dots in the head and the body, the latter being larger in size, although some populations might lack this trait. Some specimens of $H$. molango might also show dots in the body, but in this species, the dots are disperse and usually red. This species differs slightly from its sister taxon $H$. molango in its body shape, according to geometric morphometrics, and its geographic distribution (see below).

Description. Morphometric and meristic data are summarized in Tables 3-4.

Color in life. Body gray to pale yellow, sometimes vanishing to white, dark blotches extending from posterior end of the opercle to the caudal fin, sometimes forming four to six vertical bars. Head densely covered by brown or black small dots that extend from the tip of premaxilla to the basis of the dorsal fin. Most of the specimens with dots in the body that are bigger than those found in the head, fins black to yellow, dorsal, anal and caudal fin usually with small brown blotches at its base, red to purple axial mark present.

Color in alcohol. Body dark gray to brown vanishing to the ventral region, black blotches, fins white to yellow, axial mark could be absent.

Distribution. Costal lagoons and rivers in the south of Tamaulipas and North of Veracruz.

Remarks. According to Taylor \& Miller (1983; Tables 1,3), this species can be distinguished from $H$. labridens because the entire body is covered with small dark brown spots and by longer basal lengths of dorsal and anal fins and a shorter caudal peduncle. If we compare only the specimens from río Verde and exclude the non-río Verde specimens from the work of Taylor \& Miller (1983), that could correspond to another species, we can state that in H. labridens, the dorsal base length ranges from $53.6 \%$ to $58.3 \%$, the anal base length ranges from $21.2 \%$ to $24.8 \%$ and the caudal peduncle ranges from $14.4 \%$ to $17.3 \%$. Conversely, in the original material examined by Taylor \& Miller (1983), in H. pantostictus, the dorsal base length ranges from $54.3 \%$ to $60.6 \%$, the anal base length ranges from $23.3 \%$ to $27.1 \%$ and the caudal 
peduncle ranges from $13.5 \%$ to $15.6 \%$. The above-mentioned proportions were similar to those found in this study (Table 3 ); however, the overlap in the minimum and maximum values precludes their use as diagnostic characters. In a recent redescription of the species, De la Maza-Benignos \& Lozano-Vilano (2013) state that in most of the coastal and lagoon populations, the entire body is covered with dark dots, although some riverine populations lack this trait; they also state that shallow cheeks and the large eye diameter allow the differentiation of these species from the rest. Nevertheless, a close inspection of their table 4 again reveals a high overlap of these measurements with those from other species, so there is no diagnostic character that allows the differentiation of $H$. pantostictus from the rest of the species. The same is true for the number and shape of the teeth in the midline of the lower pharyngeal plate. According to De la Maza-Benignos \& Lozano-Vilano (2013), H. pantostictus can be distinguished from the rest of the species by having 6 to 7 teeth flanking the midline on each side, conic to midsize molariform and increasing in side posteriorly. Similar results were found in the specimens that we reviewed, except the number ranged from 6 to 8 teeth. Nevertheless, the same pattern was found in the specimens classified in this study as $H$. cf. labridens $(=H$. molango $)$ from Huejutla, Hidalgo, Tamazunchale, San Luis Potosí and Jaumave, Tamaulipas and even in $H$. molango (data not shown). In the map depicted in Fig. 1, we include a single locality of $H$. cf. pantostictus from río Axtla, San Luis Potosí because this specimen presents dark spots in the body, in the same way, we assess specimens from the two localities of Jaumave and río Mante, Tamaulipas as $H$. cf. labridens ( $=H$. molango) due to the lack of dark spots on the body. The above facts led us to question the existence of $H$. pantostictus and $H$. molango (including $H$. cf. labridens) as two different species, primarily because of the absence of diagnostic characters. Nevertheless, despite these findings, in the present study, $81 \%$ of the individuals identified as H. pantostictus were correctly classified in the DFA of the morphometric data adjusted as proportions (Table 1, Fig. 4). In addition, this species presents a body shape that is slightly different from that of their sister taxa H. molango (including H. cf. labridens) (Fig. 5 ) despite their shared DNA haplotypes. In such a way, $H$. pantostictus and $H$. molango could be distinguished in part by their geographic distribution, with the former distributed in South of Tamaulipas and North of Veracruz and the latter distributed in the South of San Luis Potosí and North of Hidalgo.

Material examined. Mexico: Río sobre la carretera Ocampoel Limón, Tamps. ENCB-P P5988, 2, 86.0-123.2 mm SL, río Guayalejo, Tamps. ENCB-P P5990, 7, 51.9-95.5 mm SL, río Mante, Tamps. P5991, 6, 72.7-112.7 mm SL, río Sabinas, Tamps. ENCB-P P5997, 3, 57.9-114.3 mm SL, Arroyo en el Encino, Tamps. ENCB-P P5999, 15, 58.4-116.6 mm SL, río Guayalejo, Tamps. ENCB-P P6000, 3, 65.7-86.2 mm SL, río en Nuevo Morelos, Tamps. ENCB-P P6005, 2, 118.6-140.9 mm SL, rió Tamozus, Ver. ENCB-P P6105, 5, 55.0-88.2 mm SL.

\section{Herichthys molango De la Maza-Benignos \& Lozano- Vilano, 2013}

Herichthys labridens. -León-Romero et al., 2012: 1021-1026 in part [phylogenetic analysis].

Herichthys molango De la Maza-Benignos \& Lozano-Vilano, 2013: 114-117 [original description].

Nosferatu molango. -De la Maza-Benignos et al., 2014: in press [citation].

Diagnosis. There are no unique autapomorphies that allow us to distinguish Herichthys molango from the rest of the species of the group. This species is distinguished from its sister taxon $H$. pantostictus primarily by its geographic distribution (see diagnosis of $\mathrm{H}$. pantostictus above).

Description. Morphometric and meristic data are summarized in Tables 3-4.

Color in life. A highly polymorphic species, body ranges from yellow, light brown, reddish, gray and almost black, the color vanishes in the ventral region to pale yellow or almost white. Mid half of the body with irregular black blotches that extend from opercle to the caudal fin sometimes forming four to six vertical bands, in some specimens the blotches also in dorsal and anal fin. Some individuals with red, brown or black disperse dots in the body. Head usually covered with small brown dots that could be extended to the end of the body but always following the dorsal fin, red to purple axil mark present.

Color in alcohol. Body dark brown to gray vanishing to the ventral region, most of the blotches and dots also present, fins turn white, in some specimens gray or black, axil mark might disappear.

Distribution. Widely distributed in rivers windward of the Sierra Madre Oriental in the states of Hidalgo and San Luis Potosí.

Remarks. In the original description performed by De la Maza-Benignos \& Lozano-Vilano (2013), the authors state that this species could be distinguished from the rest because it has two rows of 8 to 9 medium-sized molars that flank the midline in the lower pharyngeal plate. This result contrasts with that found in this study, where the number of teeth was only seven; additionally, the teeth were short incisives in the front and only molariforms backward. Similar results were found in other specimens that were previously classified as $H$. labridens from the states of Hidalgo and San Luis Potosí (here named $H$. cf. labridens $=$ $H$. molango). The use of pharyngeal teeth as a diagnostic character is questionable because their shape could vary with age and diet (Trapani, 2004; Muschick et al., 2011). In fact, a geometric morphometric analysis in the polymorphic species $H$. minckleyi reveals that both morphs (papilliform 
and molariform) have a similar shape and represent a single species (Trapani, 2003). Similar results were found in this study because all of the performed analyses failed to recover significant differences between $H$. molango and the specimens included in this study as $H$. cf. labridens (now $H$. molango). Thus, this is a highly polymorphic species that is distinguished from its sister taxa $H$. pantostictus mainly by its geographic distribution, as H. molango is restricted to the states of Hidalgo and San Luis Potosí. Contrary to De la Maza-Benignos \& Lozano-Vilano (2013), this species is not distributed in the río Santa María in the state of Querétaro, Mexico, because the populations distributed in this area were identified and classified as H. labridens (see above).

Material examined. Mexico: Laguna Atezca, Hgo. ENCB-P P4120, 3, 123.5-167.0 mm SL, Laguna Atezca, Hgo. ENCB-P P4140, 12, 56.0-193.0 mm SL, Laguna Atezca, Hgo. ENCB-P P4149, 4, 73.3-170.0 mm SL, Laguna Atezca, Hgo. ENCB-P P5235, 4, 63.5-66.8 mm SL, Laguna de Metztitlán, Hgo. ENCB-P P4062, 20, 72.0-109.3 mm SL, río Huichihuayan, SLP. ENCB-P P4889, 11, 81.8-99.5 mm SL, río Atlapexco, Hgo. ENCB-P P4950, 12, 86.1-159.0 mm SL, río Talol, Hgo. ENCB-P P4972, 17, 74.5122.3 mm SL, río Amajac, SLP. ENCB-P P4973, 9, 65.9-133.6 mm SL, Coacuilco, Hgo. ENCB-P P4980, 20, 74.0-108.8 mm SL, Arroyo en Ahuatempa, Hgo. ENCB-P P4981, 20, 57.0-124.4 mm SL, río Calnalí, Hgo. ENCB-P P4983, 11, 72.5-126.4 mm SL, río Atlapexco, Hgo. ENCB-P P4988, 14, 68.5-128.3 mm SL, río Santa María, Qro. ENCB-P P5036, 10, 64.5-115.3 mm SL, río Claro, SLP. ENCB-P P5919, 20, 61.1-97.1 mm SL, río Claro en Acuimantla, Hgo. ENCB-P P5920, 34, 61.8-182.6 mm SL, río Candelaria, Hgo. ENCB-P P5931, 20, 63.4-121.6 mm SL, río Mante, Tamps. ENCB-P P5993, 6, 58.6-70.6 mm SL, Arroyo between Jaumave and San Vicente, Tamps. ENCB-P P6003, 15, 80.3-113.4 mm SL, río Axtla, SLP. ENCB-P P6117, 14, 69.0-164.2 mm SL, Pueblo de Calnalí, Hgo. ENCB-P P6258, 27, 64.7-105.0 mm SL, Entre San José y Coacuilco, Hgo. ENCB-P P6267, 16, 63.3-138.5 mm SL, Cerca de Tehuatlán, Hgo. ENCB-P P 6268, 14, 64.7-158.4 mm SL.

Finally, we want to highlight two important issues that must be evaluated in later studies. First, when we compare the shapes of the body within each phylogenetic group, it is clear that the sympatric species in phylogenetic groups I and II showed greater differences in body shape than did the allopatric species in phylogenetic group III, which allows us to suggest character displacement. Second, a close inspection of Figs. 4 and 5 revealed that a similar shape could evolve independently in different lineages, most likely in response to functional and phylogenetic constraints. This is the reason that three different species, namely $H$. labridens, $H$. pame, and $H$. molango, were previously described as a single species.

\section{Discussion}

The DNA barcoding results from this study suggested the existence of three well-supported phylogenetic groups in the $H$. bartoni species group: phylogenetic group I, including haplotypes of $H$. bartoni and H. labridens from Media Luna; phylogenetic group II, including haplotypes of $H$. steindachneri and $H$. pame; and phylogenetic group III, including haplotypes of $H$. pantostictus and $H$. molango (=H. cf. labridens). However, we were unable to recover a single species as monophyletic. There are several possible explanations for these results, including maintenance of ancestral polymorphism (Moritz \& Cicero 2004) or hybridization and recent divergence among lineages (Hubert et al., 2008; Valdez-Moreno et al., 2009). Recently, Ríčan et al. (2013), using seven different molecular markers, estimate the age of phylogenetic group I, which includes $H$. bartoni and $H$. labridens at approximately 4 my. Conversely, they state that the other group of species that includes $H$. pantostictus, $H$. steindachneri, and $H$. pame have an estimated age of 4.4 my and that the most recent divergence occurred between $H$. steindachneri and $H$. pame only 1.2 my ago. Nevertheless, it is necessary to note that the ages estimated by Ríčan et al. (2013) represent the estimated mean age and are derived from only a single specimen of each species; thus, according to the $95 \%$ HPD depicted in their Fig. 2, the groups could be older or have had a very recent divergence. Hulsey \& García de León (2013), however, suggest the possible recent introgression (less than 100 years ago) of mtDNA haplotypes (without nuclear DNA introgression) of $H$. cyanoguttatus into $H$. minckleyi populations based on the presence of the same haplotype of $H$. cyanoguttatus from Tamaulipas in Cuatro Cienégas, Coahuila, discarding the maintenance of ancestral polymorphism. However, an analysis of the DNA barcodes of $H$. cyanoguttatus available in Genbank and the BOLD systems suggest the maintenance of ancestral polymorphism as a result of a species with a very high effective population size because the same haplotype was recovered in Texas and Central Mexico (data not shown).

In this work, traditional morphometrics and meristic counts failed to clearly separate species. Similar results have been found in other cichlids due to the high levels of overlap between taxonomic characters (Genner et al., 2007; Schmitter-Soto, 2007; McMahan et al., 2011; Soria-Barreto et al., 2011). In recent years, geometric morphometrics have arisen as a useful tool for discriminating species. For example, Maderbacher et al. (2008), using 17 landmarks and 9 semi landmarks for the body, were able to discriminate among three morphs of Tropheus moorii from Lake Tanganyika, whereas traditional morphometrics failed to find significant differences because meristic counts and traditional measurements are very plastic and often overlap between species. Similar results were found by Genner et al. (2007), who used geometric morphometrics of 25 landmarks from the body coupled with molecular markers and were able to discriminate between four putative sympatric species of the genus Diplotaxodon, which had previously been identified only by their nuptial coloration. However, geometric morphometrics could also 
have restrictions; for example, in a recent study of a flock species of the genus Crenicichla from Uruguay, Burress et al. (2013) failed to find significant differences among shapes from the 25 landmarks of the body evaluated, although they found significant differences in the geometric morphometrics of the lower pharyngeal plate. In conclusion, the results of this study regarding geometric morphometrics allow support for the recent proposal of De la Maza-Benignos \& Lozano-Vilano (2013) that $H$. labridens s.l. comprises several species. However, further studies with other molecular markers are necessary to recover the monophyly of each species and elucidate the speciation patterns in the $H$. bartoni species group.

\section{Acknowledgments}

This study was funded by SIP project number 20121320. We also thank to Jorge Romero-Castillo and Mario Valencia Infante for field assistance, Jon Richey for kindly review the translated manuscript and an anonymous reviewer for their useful comments.

\section{References}

Bean, T. H. 1892. Notes on fishes collected in Mexico by Prof. Alfredo Dugès, with descriptions of new species. Proceeding of the United States National Museum,15: 283-287.

Burress, E. D., A. Duarte, W. S. Serra, M. Loureiro, M. M. Gangloff \& L. Siefferman. 2013. Functional diversification within a predatory species flock. PLOS One, 8:11.

Butler, M. A. \& J. B. Losos. 2002. Multivariate sexual dimorphism, sexual selection, and adaptation in Greater Antillean Anolis lizards. Ecological Monographs, 72: 541-559.

Concheiro-Pérez, G., L. Oldlich, G. Ortí, E. Bermingham, I. Doadrio \& R. Zardoya. 2007. Phylogeny and biogeography of 91 species of heroine cichlids (Teleostei: Cichlidae) based on sequences of the cytochrome $b$ gene. Molecular Phylogenetics and Evolution, 43: 91-110.

De la Maza-Benignos, M. \& M. L. Lozano-Vilano. 2013. Description of three new species of the genus Herichthys (Perciformes: Cichlidae) from eastern Mexico, with redescription of $H$. labridens, $H$. steindachneri, and $H$. pantostictus. Zootaxa, 3734: 101-129.

De la Maza-Benignos, M., C. P. Ornelas-García, M. L. Lozano-Vilano, M. E. García-Ramírez \& I. Doadrio. 2015. Phylogeographic analysis of genus Herichthys (Perciformes: Cichlidae), with descriptions of Nosferatu new genus and $H$. tepehua n. sp. Hydrobiologia, 748: 201-231.

Elmer, K. R., H. Kusche, T. K. Lehtonen \& A. Meyer. 2010. Local variation and parallel evolution: morphological and genetic diversity across a species complex of neotropical crater lake cichlid fishes. Philosophical Transactions of the Royal Society of London series B 365: 1763-1782.

Genner, M., P. Nichols, G. Carvalho, R. Robinson, P. Shaw \& G. Turner. 2007. Reproductive isolation among deep-water cichlid fishes of Lake Malawi differing in monochromatic male breeding dress. Molecular Ecology, 16: 651-662.

Hammer, Ø., D. A. T. Harper \& P. D. Ryan. 2001. PAST: Paleontological Statistics Software Package for Education and Data Analysis v 3.01. Palaeontologia Electronica 4.
Hubert, N., R. Hanner, E. Holm, N. E. Mandrak, E. Taylor, M. Burridge, D. Watkinson, P. Dumont, A. Curry, P. Bentzen, J. Zhang, J. April \& L. Bernatchez. 2008. Identifying Canadian Freshwater Fishes through DNA Barcodes. PLOS One, 3: e2490.

Hulsey, C. D. \& F. García de León. 2013. Introgressive hybridization in a trophically polymorphic cichlid. Ecology and Evolution, 3: 4536-4547.

Hulsey, C. D., F. García de León, Y. Sánchez, D. Hendrickson \& T. Neara. 2004. Temporal diversification of Mesoamerican cichlid fishes across a major biogeographic boundary. Molecular Phylogenetics and Evolution, 31: 754-764.

Jordan, D. S. \& J. O. Snyder. 1899 . Notes on a collection of fishes from the rivers of Mexico, with description of twenty new species. Bulletin of the U.S. Fish Commission, 115147.

Klingenberg, C. P. 2011. MorphoJ: an integrated software package for geometric morphometrics. Molecular Ecology Resources, 11: 353-357.

Klingenberg, C. P., M. Barluenga \& A. Meyer. 2003. Body shape variation in cichlid fishes of the Amphilophus citrinellus species complex. Biological Journal of the Linnean Society, 80: 397-408.

Kullander, S. 1996. Heroina inonycterina, a new genus and species of cichlid fish from Western Amazonia, with comments on Cichlasomine systematic. Ichthyological Exploration of Freshwaters, 7: 149-172.

Langerhans, R. B., C. A. Layman, A. K. Langerhans \& T. J. Dewitt. 2003. Habitat-associated morphological divergence in two neotropical fish species. Biological Journal of the Linnean Society, 80: 689-698.

León-Romero, Y., O. Mejía \& E. Soto-Galera. 2012. DNA barcoding reveals taxonomic conflicts in the Herichthys bartoni species group (Pisces: Cichlidae). Molecular Ecology Resources, 12: 1021-1026.

Maderbacher, M., C. Bauer, J. Herler, L. Postl, L. Makasa \& C. Sturmbauer. 2008. Assessment of traditional versus geometric morphometrics for discriminating populations of the Tropheus moorii species complex (Teleostei: Cichlidae), a Lake Tanganyika model for allopatric speciation. Journal of Zoological Systematics and Evolutionary Research, 46: 153-161.

McMahan, C. D., C. M. Murray, A. D. Geheber, C. D. Boeckman \& K. R. Piller. 2011. Paraneetroplus synspilus is a junior synonym of Paraneetroplus melanurus (Teleostei: Cichlidae). Zootaxa, 2833: 1-14.

Meek, S. E. 1904. The freshwater fishes of Mexico north of the isthmus of Tehuantepec. Zoological Series, Field Columbian Museum, Chicago, 5: 210-212.

Mejía, O., Y. León-Romero \& E. Soto-Galera. 2012. DNA barcoding of the ichthyofauna of Pánuco-Tamesí complex: evidence for taxonomic conflicts in some groups. Mitochondrial DNA, 23: 471-476.

Miller, R. R. 1966. Geographical distribution of Central American freshwater fishes. Copeia, 1966: 773-802.

Miller, R. R., W. L. Minckley \& S. M. Norris. 2005. Freshwater Fishes of Mexico., Chicago,University of Chicago Press.

Miller, R. R. 1976. An evaluation of Seth E. Meek's contributions to Mexican ichthyology. Fieldiana Zoology, 69:1-31.

Moritz C. \& C. Cicero.2004. DNA barcoding: Promise and pitfalls. PLoS Biology, 2: e354. 
Muschick, M., M. Barluenga, W. Salzburger \& A. Meyer. 2011. Adaptive phenotypic plasticity in the Midas cichlid fish pharyngeal jaw and its relevance in adaptive radiation. BMC Evolutionary Biology, 11: 116.

Pellegrin, J. 1903. Description de Cichlidés nouveax de la collection du Muséum. Bulletin du Musée National d'Histoire Naturelle, 9: 120-125.

Regan, C.T. 1905. Pisces. London, Biologia Centrali Americana, R.H. Porter.

Říčan, O., L. Piálek, R. Zardoya, I. Doadrio \& J. Zrzavy. 2013. Biogeography of the Mesoamerican Cichlidae (Teleostei: Heroini): colonization through the GAARlandia land bridge and early diversification. Journal of Biogeography, 40: 579593.

Říčan, O., R. Zardoya \& I. Doadrio. 2008. Phylogenetic relationships of Middle American cichlids (Cichlidae, Heroini) based on combined evidence from nuclear genes, mtDNA, and morphology. Molecular Phylogenetics and Evolution, 49: 941-957.

Rohlf, F. J. 2010. tpsdig version 2.16. Department of Ecology and Evolution, State University of New York at Stony Brook, New York.

Rohlf, F. J. 2012. tpsUtil version 1.53. Department of Ecology and Evolution, State University of New York at Stony Brook, New York.

Schmitter-Soto, J. J. 2007. A systematic revision of the genus Archocentrus (Perciformes: Cichlidae) with the description of two new genera and six new species. Zootaxa, 1603: 1-78.

\section{Appendix}

Localities, number of catalog and number of individuals examined in this study for the geometric morphometric analysis.

Herichthys bartoni. Mexico: ENCB-P P3880, 8, Laguna de la Media Luna, SLP, ENCB-P P6108, 12, Manantial los Anteojos, río Verde, SLP.

Herichthys cf. labridens. Mexico: ENCB-P P4062, 20, Laguna de Metztitlán, Hgo.; ENCB-P P4889, 10, río Huichihuayan, SLP. ENCB-P P4950, 12, río Atlapexco, Hgo. ENCB-P P4972, 17, río Talol, Hgo. ENCB-P P4973, 8, río Amajac, SLP. ENCB-P P4980, 20, Coacuilco, Hgo. ENCB-P P4981, 20, Arroyo in Ahuatempa, Hgo. ENCB-P P4983, 11, río Calnalí, Hgo. ENCB-P P4988, 14, río Atlapexco, Hgo. ENCB-P P5036, 10, río Santa María, Qro. ENCB-P P5919, 20, río Claro, SLP. ENCB-P P5920, 34, río Claro en Acuimantla, Hgo. ENCB-P P5931, 19, río Candelaria, Hgo. ENCB-P P5993, 6, río Mante, Tamps. ENCB-P P6003, 16, Arroyo between Jaumave and San Vicente, Tamps. ENCB-P P6117, 13, río Axtla, SLP. ENCB-P P6258, 20, Pueblo de Calnalí, Hgo. ENCB-P P6266, 11, San Pedro Huazalingo, Hgo. ENCB-P P6267, 16, Between San José and Coacuilco, Hgo. ENCB-P P6268, 14, Nearof Tehuatlán, Hgo. ENCB-P P6294, 14, San Felipe Orizatlán, Hgo.
Sheets, H., D. Swiderski \& M. Zelditch. 2001.IMP series. Available from: http://www3.canisius.edu/ sheets/morphsoft.html

Soria-Barreto, M., R. Rodiles-Hernández \& A. A. GonzálezDíaz. 2011. Morfometría de las especies de Vieja (Cichlidae) en ríos de la cuenca del Usumacinta, Chiapas, México. Revista Mexicana de Biodiversidad, 82: 569-579.

Taylor, J. N. \& R. R. Miller. 1983. Cichlid fishes (Genus Cichlasoma) of the Rio Panuco basin, Eastern Mexico, with description of a new species. Occasional Papers of the Museum of Natural History University of Kansas, 104: $1-24$.

Trapani, J. 2003. Geometric morphometric analysis of body-form variability in Cichlasoma minckleyi, the Cuatro Cienegas cichlid. Environmental Biology of Fishes, 68: 357-369.

Trapani, J. 2004. A morphometric analysis of polymorphism in the pharyngeal dentition of Cichlasoma minckleyi (Teleostei: Cichlidae). Archives of Oral Biology, 49: 825-835.

Valdez-Moreno, M., N. V. Ivanova, M. Elías-Gutiérrez, S. Contreras-Balderas \& P. D. N. Hebert. 2009. Probing diversity in freshwater fishes from Mexico and Guatemala with DNA barcodes. Journal of Fish Biology, 74: 377-402.

Submitted February 4, 2014 Accepted October 6, 2014 by Claudio de Oliveira Published March 31, 2015

Herichthys labridens. Mexico: ENCB-P P3770, 11, río Verde, SLP. ENCB-P P4866, 6, río Jalpan, Qro. ENCB-P P5041, 20, río Conca, Qro. ENCB-P P5061, 20, río Manzanares, Gto. ENCB-P P6011, 3, Canal de la Media Luna, SLP. ENCB-P P6012, 2, río Verde, SLP. ENCB-P P6016, 8, río Calabazas, SLP.

Herichthys pantostictus. Mexico: ENCB-P P5988, 2, río sobre la carretera Ocampo-el Limón, Tamps. ENCB-P P5990, 5, río Guayalejo, Tamps. ENCB-P P5991, 6, río Mante, Tamps. ENCB-P P5997, 3, río Sabinas, Tamps. ENCB-P P5999, 16, Arroyo in Encino, Tamps. ENCB-P P6000, 4, río Guayalejo, Tamps. ENCB-P P6003, 1, Arroyo between Jaumave and San Vicente, Tamps. ENCB-P P6005, 2, río en Nuevo Morelos, Tamps. ENCB-P P6105, 6, río Tamozus, Ver. ENCB-P P6117, 1, río Axtla, SLP.

Herichthys steindachneri. Mexico: ENCB-P P82, 9, El Pujal, SLP. ENCB-P P1742, 5, Ciénega cerca de Jaumave, Tamps. ENCB-P P3898, 1, Tamasopo, SLP. ENCB-P P4823, 1, El Rodeo. ENCB-P P4876, 1, Agua Buena, SLP. ENCB-P P6010,5, Cascadas de Tamasopo, SLP. ENCB-P P6111, 5, río Gallinas, SLP. ENCB-P P6114, 9, río Tamasopo, SLP.

Herichthys pame. Mexico: ENCB-P P4758, 10, Cascadas de Tamasopo, SLP.

Herichthys molango. Mexico: ENCB-P P5235, 3, Laguna Atezca, Hgo. 